\title{
FAITH-BASED MARKETING: ANTECEDENTS OF PURCHASE INTENTION FOR HALAL-CERTIFIED PERSONAL CARE PRODUCTS
}

\author{
Hanif Adinugroho Widyanto', Muhammad Khalil Irfanur ${ }^{2}$ \\ ${ }^{1}$ School of Business, President University \\ Email: hanif@president.ac.id \\ ${ }^{2}$ Independent Researcher, Jakarta \\ Email: halilirfanur@gmail.com
}

Masuk : dd-mm-yyyy, revisi: dd-mm-yyyy, diterima untuk diterbitkan : dd-mm-yyyy

\begin{abstract}
ABSTRAK
Tujuan dari penelitian ini adalah untuk menemukan faktor-faktor yang mempengaruhi minat membeli konsumen terhadap produk perawatan pribadi yang tersertifikasi halal. Faktor-faktor yang mempengaruhi niat membeli konsumen adalah religiusitas, kesadaran halal, sertifikasi halal, persepsi pribadi tentang masyarakat, dan pemasaran halal. Penelitian ini menggunakan metode survei dengan kuesioner sebagai instrumen untuk mengumpulkan data dan diberi skor menggunakan Skala Likert dan dianalisa dengan metode regresi berganda pada aplikasi SPSS 24. Penelitian ini dilakukan di wilayah Jabodetabek dengan total 309 responden. Hasil penelitian ini menunjukkan bahwa religiusitas dan kesadaran halal tidak memiliki pengaruh signifikan terhadap niat beli untuk produk perawatan pribadi bersertifikat halal. Selain itu, sertifikasi halal, persepsi pribadi dan masyarakat, dan pemasaran halal ditemukan memiliki pengaruh signifikan terhadap niat pembelian produk perawatan pribadi bersertifikat halal. Semua variabel memiliki pengaruh signifikan secara simultan terhadap niat pembelian produk perawatan pribadi bersertifikat halal. Hasil dari penelitian ini dapat memberikan masukan bagi perusahaan terkait pentingnya melakukan sertifikasi halal bagi produk perawatan pribadi yang mereka produksi agar dapat meningkatkan minat membeli konsumen, dan menentukan secara tepat strategi pemasaran mereka.
\end{abstract}

Kata Kunci: Minat Pembelian, Sertifikasi Halal, Religiusitas, Kesadaran Halal, Pemasaran Halal

\section{ABSTRACT}

The purpose of this research was to find out the factors influencing consumer's purchase intention toward halalcertified personal care products. The factors influencing consumer's purchase intention investigated in this study were religiosity, halal awareness, halal certification, personal societal perception, and halal marketing. This research is a quantitative research with questionnaire as the instrument to gather the data and was scored using the Likert Scale and analyzed with multiple regression on SPSS 24. This research was conducted in the Greater Jakarta area with a total of 309 respondents. The results of this research showed that religiosity and halal awareness had no significant influence toward purchase intention for halal-certified personal care products. Additionally, personal societal perception, halal certification, and halal marketing were found to have significant influences toward purchase intention of halal-certified personal care products. Finally, all the variables had simultaneously significant influence on purchase intention of halal-certified personal care products. The results of this study could provide companies with a valuable insight regarding the importance of and urgency for halal-certifying their personal care products to improve customer's purchase intention, and to set their marketing strategy accordingly.

Keywords: Purchase Intention, Halal Certification, Religiosity, Halal Awareness, Halal Marketing

\section{INTRODUCTION}

\section{Background}

Islam is the second largest and fastest growing religion, and it is projected that $26.4 \%$ of the global population are expected to be Muslims by 2030 (Euromonitor International, 2015; Pew Research Center, 2011), and would increase further to $31.1 \%$ by 2060 (Lipka \& Hackett, 2017). With the growing population of Muslims, so does the demand for Halal-based products which is commonly associated with foods and beverages (Fazira \& Chan, 2018). The Arabic word for halal means "permissible", and the opposite word is haram which means "prohibited" (Abd Rahman, Asrarhaghighi, \& Ab Rahman, 2015; Wilson \& Liu, 2010). Products which contain 
pork-related components, alcohol, and livestocks slaughtered without following the sharia law are considered haram (Abd Rahman et al., 2015). Therefore, halal certification of products plays an important role to comply with the sharia law and assure the reliability of the halal products. However, contrary to popular belief, the concept of halal is not limited to food and beverages only, but also covers other products and services such as pharmaceuticals, hospitality and tourism, and personal care products. Multinational companies from non-Islamic countries have recognized halal markets potential and enjoyed $90 \%$ of market share in halal foods, cosmetics, and medicines (Islam \& Chandrasekaran, 2013). Thomson Reuters (2016) reported that the global personal care/cosmetics consist of $27 \%$ of skin care, $23 \%$ mixed products (e.g. toothpaste, deodorants, and other personal care products), 20\% make up, $20 \%$ hair care, and $10 \%$ fragrance.

In this regard, as the world's largest Muslim population in the world with around 207 million Muslims as of 2017 (Badan Pusat Statistik, 2017), Indonesia has a huge potential market for halal personal care products (Aisyah, 2017). Additionally, according to Aiyer (2018), Indonesia's halal market grew at over 9\% compounded annual growth rate (CAGR), compared to the global CAGR at 3\% per year between 2014 and 2019, which has positioned the country as the $6^{\text {th }}$ leading CAGR market in the world. Unfortunately, Indonesia still lags behind other Muslim-majority countries in terms of the Islamic economy, with the country ranking $10^{\text {th }}$ out of the 73 countries listed on the Global Islamic Economy (GIE) Indicator Score (The Jakarta Post, 2017). However, the country exhibits a huge potential in the halal pharmaceuticals and cosmetics sector, ranking 8th out of ten Muslim-majority countries. Indonesia is also in the top three countries for halal cosmetics and personal care products expenditure, behind Russia and India that seized the top markets with a combined value of $\$ 3.3$ billion (Thomson Reuters, 2016). According to Indonesia Investments (2017), the personal care and cosmetics industry value in Indonesia was estimated to reach $\$ 2.7$ billion in 2016 , a $12 \%$ increase from the previous year. One of the rising stars in the local halal industry was Wardah, which saw its share increasing from just 1\% in 2009 to nearly 5\% in 2014 (Euromonitor International, 2016). Unilever and Colgate had also followed suit by launching halal-certified products (Spencer, 2016). Hence, companies operating in Indonesia should have a huge incentive to halal-certify their products ingredients to follow the consumer's preferences (EU-Indonesia Business Network, 2019).

Unfortunately, products that have been halal-certified in Indonesia are still less than $10 \%$ of the total number of products available in the market (Permana, 2019). This happens due to the lack of awareness and urgency for companies to halal-certify their products (Aisyah, 2017). Therefore, the purpose of this study is to understand the growing importance of halal certification in Indonesia, especially for personal care products of which the country has a huge market potential. In particular, the researchers would like to analyze the antecedents of customer's purchase intention for halal-certified personal care products to provide valuable insights for companies in the industry which are still unconvinced about the importance of halal certification. Understanding customer's purchase intention is also important to comprehend the factors that form an intention for buying a product or service (Nurcahyo \& Hudrasyah, 2017). Based on the theory of planned behavior (TPB) by Ajzen (2015), there are three dimensions of personal societal perception that support purchase intention, namely, attitude, subjective norms, and perceived behavioral control.

To begin with, attitude can be defined as the review of one's assessments and general appraisals in relation to any information regarding a brand (Keller, 2003). In other words, attitude is based on the consumer's belief and knowledge regarding certain commodity, which is a deduced information of integration process and ultimately associated with the individual's reaction (Xiao, 
Ford, \& Kim, 2011). Additionally, several other studies in the past (e.g. Bonne, Vermeir, Bergeaud-Blackler, \& Verbeke, 2007; Weng \& Khin, 2017) have also investigated the positive effect between attitude and purchase intention for halal products. Secondly, Ajzen (2015) explained that subjective norm is a perceived pressure by peers to carry out certain behavior. Muslims believe in the teaching of Prophet Muhammad who embraced and displayed exemplary halal behavior for his followers to abide by (Aisyah, 2017). Therefore, subjective norms can also be used to predict halal purchase intention (Awan, Siddiquei, \& Haider, 2015; Lada, Tanakinjal, \& Amin, 2009; Mukhtar \& Mohsin Butt, 2012). Finally, perceived behavioral control is defined as assessments of whether or not certain certain behavior is considered to be controllable (Awan et al., 2015). Perceived behavior is one of the important factors of an individual's intention toward purchasing decision. According to Ajzen (2015), perception of behavioral control is understood to consistently adhere to predetermined beliefs that are readily available. Previous studies have established the relationship between perceived behavioral control and purchase intention (Alam \& Sayuti, 2011; Bonne et al., 2007).

To better understand the antecedents of purchase intention for halal-certified personal care product among consumers, the researchers also extended the predicting factors by incorporating religiosity, halal awareness, halal certification, and halal marketing in accordance with Awan et al. (2015) and Nurcahyo and Hudrasyah (2017). Firstly, religiosity is defined as the spiritual value which serves as a behavioral benchmark to decide on alternatives for halal purchasing (Awan et al., 2014). Meanwhile, Bakar, Lee, and Hashim (2013) explained that religiosity is regarded as one's belief in the Almighty and commitment to follow the principles set by Him. According to Mukhtar and Butt (2012), an individual's own level of religiosity positively affects attitude toward halal products. Several studies in the past have analyzed the relationship between religiosity and buying behavior (Alam, Rohani, \& Hisham, 2011; Varinli, Erdem, \& Avcilar, 2016).

Next, halal awareness is the level of understanding for Muslims to be fully conscious regarding the concept of halal and shape their decision in buying and consuming halal products. (Nurcahyo \& Hudrasyah, 2017). However, halal products are not just limited to food and beverages. According to Islam and Chandrasekaran (2013), there are three other categories for halal products and services, namely, halal cosmetics and personal care, halal pharmaceuticals, and halal hospitality and tourism. Therefore, it is imperative for Muslim consumers to know if the products they buy and use are categorized as halal (Awan et al., 2014). According to Alam and Sayuti (2011), despite the wide variety of halal product assortments and general information regarding the halal market, there are only a handful of studies dedicated on halal purchasing. Therefore, it is important for Muslims to have an understanding and knowledge on what is halal as a standard for measuring halal awareness (Bin Jamari, Nadzirah, Samingin, Pandiyan, \& Sundram, 2011). Previous studies have investigated and confirmed the positive relationship between halal awareness and purchase intention (Alam \& Sayuti, 2011; Aziz \& Chok, 2013; Lada et al., 2009; Syukur \& Nimsai, 2018).

Halal certification is an imperative factor in a Muslim's consumption decision on whether the product that they purchased is Halal or not. Halal directives and accreditation system were formed to facilitate Muslim consumers to purchase halal products which follow the fundamental principles practiced in Islam (Awan et al., 2014). According to Islam and Chandrasekaran (2013), halal certificate is a document issued and approved by an Islamic organization which certifies that the product meets the Islamic law and is usable/edible by the Muslims. Finally, Halal marketing follows the notion that religion has an affect for consumer choices and thus, by 
adhering to the Islamic law, principle, and guidelines for strategic marketing, brands can make their decision for communication and delivering products and services to consumers (Islam \& Chandrasekaran, 2013). Earlier studies by Aziz and Chok (2013) and Awan et al. (2015) have found the relationship between halal marketing and customer's purchase intention.

Therefore, this research aims to investigate the predicting effects of personal societal perception, religiosity, halal awareness, halal certification, and halal marketing as independent variables toward purchase intention of halal-certified personal care products in the Greater Jakarta (Jabodetabek) area. This study important particularly for businesses to understand the predictors of purchase intention for halal-certified personal care products since the government of Indonesia has just enacted Law no. 33 of 2014 which requires all products sold in the country - not just foods and beverages - to be halal-certified, which is met with resistance by many stakeholders. Specifically, the researchers choose halal-certified personal care product since Indonesia has the world's third largest consumer market in halal pharmaceuticals and personal care products (Thomson Reuters, 2016), but the topic is still rarely investigated in the past.

\section{RESEARCH METHODS}

For this research, questionnaire is used as the main instrument for data gathering from the respondents. The questionnaire consists of respondent's profiles and their opinion for each question that represents the variables using the Likert's scale system. In this study, the researchers examine Muslim populations living in the area of Greater Jakarta (i.e., Jakarta, Bogor, Depok, Tangerang, and Bekasi) - one of the largest megapolitan areas in the world - who have purchased halal-certified personal care products in the past. The researchers use nonprobability sampling because the targeted samples do not have equal probability to be chosen as a subject for the research (Sekaran \& Bougie, 2016). The total number respondents in this research is 309 people. Table 1 lists the operational definitions of the variables, which includes the definition and indicators of every variable explored in this study.

Table 1. Operational Definitions of the Variables

\begin{tabular}{|c|c|c|}
\hline Variables & Indicators & Statements \\
\hline $\begin{array}{l}\text { Personal } \\
\text { Societal } \\
\text { Perception }\end{array}$ & $\begin{array}{l}\text { - } \text { Subjective norms } \\
\text { - Perceived behavioral } \\
\text { control } \\
\text { - Attitude } \\
\text { (Awan et al., 2014; } \\
\text { Nurcahyo \& Hudrasyah, } \\
\text { 2017) }\end{array}$ & $\begin{array}{l}\text { - For me, I would give priority for halal-certified personal } \\
\text { care product } \\
\text { - For me, there are a lot of halal-certified personal care } \\
\text { product that I can choose from } \\
\text { - For me, I would give considerable effort to obtain a halal- } \\
\text { certified personal care product even if it means travelling } \\
\text { long distances } \\
\text { - People have a positive perception towards halal-certified } \\
\text { personal care product }\end{array}$ \\
\hline Religiosity & $\begin{array}{l}\text { - Religiosity } \\
\text { - Religious Commitment } \\
\text { (Awan et al., 2014; Bakar } \\
\text { et al., 2013) }\end{array}$ & $\begin{array}{l}\text { - Generally speaking, I would consider myself as a } \\
\text { religious person } \\
\text { - I would follow religious advice that compels me to } \\
\text { purchase halal products } \\
\text { - I try to avoid purchasing products that are considered } \\
\text { "makrooh" (should not be done by a Muslim) } \\
\text { - I choose halal-based products because it has better family } \\
\text { and social acceptance } \\
\text { - I choose halal products because of my religious } \\
\text { conviction }\end{array}$ \\
\hline
\end{tabular}




\begin{tabular}{|c|c|c|}
\hline Variables & Indicators & Statements \\
\hline $\begin{array}{l}\text { Halal } \\
\text { Awareness }\end{array}$ & $\begin{array}{l}\text { - Awareness } \\
\text { - Halal importance } \\
\text { - Knowledge } \\
\text { (Awan et al., 2014; Haque } \\
\text { et al., 2015; Nurcahyo \& } \\
\text { Hudrasyah, 2017) }\end{array}$ & $\begin{array}{l}\text { - I would ensure that the personal care product I purchase } \\
\text { is halal } \\
\text { - I would ensure that the personal care product that I use } \\
\text { have halal ingredients or component in it } \\
\text { - I always ensure to have enough knowledge whether a } \\
\text { personal care product is halal or not before making a } \\
\text { purchase decision } \\
\text { - Generally speaking, manufacturers are responsible for } \\
\text { halal-certified personal care product availability } \\
\text { - Generally speaking, government is responsible for halal- } \\
\text { certified personal care product availability }\end{array}$ \\
\hline $\begin{array}{l}\text { Halal } \\
\text { Certification }\end{array}$ & $\begin{array}{l}\text { - Accreditation } \\
\text { - Knowledge } \\
\text { - Sharia law } \\
\text { - Halal importance } \\
\text { (Awan et al., 2014; Aziz } \\
\text { \& Chok, 2013; Nurcahyo } \\
\text { \& Hudrasyah, 2017) }\end{array}$ & $\begin{array}{l}\text { - I believe Halal certification for Personal Care Products is } \\
\text { Important } \\
\text { - for me, Halal certified personal care products improve the } \\
\text { product market ability } \\
\text { - I prefer to buy personal care product that is halal certified } \\
\text { - For me, Halal certified personal care products is more } \\
\text { attractive }\end{array}$ \\
\hline $\begin{array}{l}\text { Halal } \\
\text { Marketing }\end{array}$ & $\begin{array}{l}\text { - Brand image } \\
\text { - Advertising } \\
\text { - Quality } \\
\text { (Awan et al., 2014; Islam } \\
\text { \& Chandrasekaran, 2013; } \\
\text { Wilson \& Liu, 2010) }\end{array}$ & $\begin{array}{l}\text { - Brand is an important consideration for purchasing halal- } \\
\text { certified personal care product } \\
\text { - I purchase halal-certified personal care product with a } \\
\text { familiar brand that I know } \\
\text { - For me, Religious Public figure or celebrity helps } \\
\text { influence my decision in purchasing halal-certified } \\
\text { personal care product } \\
\text { - I always make sure about the quality of the halal-certified } \\
\text { personal care product that I purchased } \\
\text { - Sales promotion influences me for purchasing halal- } \\
\text { certified personal care product }\end{array}$ \\
\hline $\begin{array}{l}\text { Purchase } \\
\text { Intention }\end{array}$ & $\begin{array}{l}\text { - Purchase decision } \\
\text { - Recommendation } \\
\text { - Willingness } \\
\text { - Satisfaction } \\
\text { (Awan et al., 2014; Haque } \\
\text { et al., 2015; Nurcahyo \& } \\
\text { Hudrasyah, 2017; Kim \& } \\
\text { Chung, 2011) }\end{array}$ & $\begin{array}{l}\text { - I am likely to purchase halal-certified personal care } \\
\text { product } \\
\text { - I feel satisfied when I'm buying halal-certified personal } \\
\text { care product } \\
\text { - I am willing to pay more to purchase halal-certified } \\
\text { personal care products } \\
\text { - I would likely purchase halal-certified personal care } \\
\text { product because of recommendation from family or } \\
\text { friends } \\
\text { - I would likely recommend my friend and family to halal- } \\
\text { certified personal care product }\end{array}$ \\
\hline
\end{tabular}

\section{RESULT AND DISCUSSION}

For the validity test, the researchers used the Pearson Method. The data for validity test are obtained from an online form that was converted to a spreadsheet application and processed by using a statistical tool with the level of significance of 0.05 . Validity test is done to ensure that all the variable in the questionnaire are valid for distribution by comparing each of the item $r$ with the r-table. Based on the validity test, all the statements used to measure the variables in this study have been found to be "valid". The reliability test is also conducted to avoid inconsistency in the questionnaires. In this regard, the researchers followed Garson (2012) which explained that for the variables to be considered reliable, they need to have Cronbach's Alpha of more than 0.60. Based on the reliability test in this study, all variables are found to be reliable.

The test for classical assumption in this study includes normality test, heteroscedasticity test, and multicollinearity test. Data normality is analyzed based on histogram and P-P plot. The 
histogram in this study shows a "Bell-Shaped" curve, which signifies normally distributed errors. For the P-P plot, the dots form a pattern which follow the diagonal line. This also indicates normal distribution. Heteroscedasticity test is utilized to check if there was any identical variance in the residual data by using scatter plot. The result indicates that the dots do not follow a pattern and are dispersing all over the place. Therefore, it can be inferred that the multiple regression equation is considered to be "valid" since there are different variances in the residuals and can be used in this research. Finally, in the multicollinearity test, the tolerance value should be below 10 and the VIF (Value Inflation Factor) must be more than 0.2. Based on Table 3, it can be seen that there is no multicollinearity between the independent variables.

Table 2. Multiple Linear Regression Analysis

\begin{tabular}{|c|c|c|c|c|c|c|c|}
\hline \multirow[b]{3}{*}{ Model } & & & \multirow{3}{*}{$\begin{array}{l}\text { Coefficients }{ }^{\mathrm{a}} \\
\text { Standardized } \\
\text { Coefficients } \\
\text { Beta }\end{array}$} & \multirow[b]{3}{*}{$\mathbf{t}$} & \multirow[b]{3}{*}{ Sig. } & \multirow{2}{*}{\multicolumn{2}{|c|}{$\begin{array}{l}\text { Collinearity } \\
\text { Statistics }\end{array}$}} \\
\hline & \multicolumn{2}{|c|}{$\begin{array}{l}\text { Unstandardized } \\
\text { Coefficients }\end{array}$} & & & & & \\
\hline & B & Std. Error & & & & Tolerance & VIF \\
\hline 1 (Constant) & -2.012 & 0.911 & & -2.209 & 0.028 & & \\
\hline $\begin{array}{l}\text { Personal } \\
\text { Societal } \\
\text { Perception }\end{array}$ & 0.438 & 0.061 & 0.402 & 7.194 & 0.000 & 0.267 & 3.749 \\
\hline Religiosity & 0.105 & 0.054 & 0.080 & 1.945 & 0.053 & 0.489 & 2.047 \\
\hline $\begin{array}{l}\text { Halal } \\
\text { Awareness }\end{array}$ & 0.055 & 0.054 & 0.053 & 1.023 & 0.307 & 0.312 & 3.209 \\
\hline $\begin{array}{l}\text { Halal } \\
\text { Certification }\end{array}$ & 0.329 & 0.078 & 0.237 & 4.239 & 0.000 & 0.266 & 3.753 \\
\hline $\begin{array}{l}\text { Halal } \\
\text { Marketing }\end{array}$ & 0.211 & 0.037 & 0.215 & 5.626 & 0.000 & 0.570 & 1.754 \\
\hline
\end{tabular}

a. Dependent Variable: Purchase Intention

Based on Table 2, the multiple regression analysis shows that out of the five independent variables, there are two variables, which are religiosity and halal awareness, that do not have any significant relationships with the purchase intention to buy halal-certified personal care products, while the other variables were found to be significantly related with the dependent variable. Hence, the following multiple regression formula is generated:

Where:

$$
Y=-2.012+.438 X 1+.329 X 4+.211 X 5
$$

$\begin{array}{ll}\mathrm{Y}= & \text { Purchase Intention Toward Halal-Certified Personal Care Products } \\ \mathrm{X} 1= & \text { Personal Societal Perception } \\ \mathrm{X} 4= & \text { Halal Certification } \\ \mathrm{X} 5= & \text { Halal Marketing }\end{array}$

Table 3. Relationship Among Constructs

\begin{tabular}{lcccc}
\multicolumn{1}{c}{ Casual Relationship Among Constructs } & Beta & T & Sig. & Decision \\
\hline $\begin{array}{l}\text { Personal Societal Perception } \rightarrow \text { Purchase } \\
\text { Intention }\end{array}$ & 0.438 & 7.194 & .000 & Supported \\
\hline Religiosity $\rightarrow$ Purchase Intention & 0.105 & 1.945 & .053 & Not Supported \\
\hline Halal Awareness $\rightarrow$ Purchase Intention & 0.055 & 1.023 & .307 & Not Supported \\
\hline Halal Certification $\rightarrow$ Purchase Intention & 0.329 & 4.239 & .000 & Supported \\
\hline Halal Marketing $\rightarrow$ Purchase Intention & 0.211 & 5.626 & .000 & Supported \\
\hline$*$ Significant $<\mathbf{0 . 0 5}$ & & & &
\end{tabular}

Based on Table 3, personal societal perception shows a significant influence toward purchase intention. From the T-test, it is found that the t-value for personal societal perception is 7.194 and the significance level is 0.00 , which is below the significance level of 0.050 . Previous 
studies by Awan et al. (2015) and Nurcahyo and Hudrasyah (2017) supported the finding of the current study which found that personal societal perception has a significant influence on purchase intention. On the other hand, religiosity shows no significant influence toward purchase intention. The $t$-value of religiosity is 1.945 with a significance value of $0.053(>0.05)$. This is contrary to the previous research by Awan et al. (2014). However, it is worth noting that most studies on the topic in the past mostly focused on halal foods and beverages, which are the most accepted concept of halal. Conversely, halal awareness also shows that there is no significant influence toward purchase intention with a t-value of 1.023 and the significance value of 0.307 (>0.05). This is contrary to the finding by Bin Jamari et al. (2011). However, the finding of the current study is supported by Awan et al. (2015) and Nurcahyo and Hudrasyah (2017), which discovered that halal awareness does not affect consumer's intention to purchase.

Halal certification shows significant influence on purchase intention. From the T-test, halal certification t-value is 4.239 with a significance value of $0.00(<0.05)$. This is supported by Awan et al. (2015) and Nurcahyo and Hudrasyah (2017). For many Muslims, halal certification can put their mind at ease and increase their trust, satisfaction, and loyalty (Chairani, 2019), resulting in a potential sales boost for businesses with halal certification (Soraya, 2018). Finally, there is a significant influence between halal marketing and purchase intention, with a t-value of 5.626 and a significance value of $0.00(<0.05)$. This is in line with Awan et al. (2015) and Nurcahyo and Hudrasyah (2017), which discovered significant influence of halal marketing toward purchase intention.

\section{Table 4. ANOVA/F-Test Analysis} ANOVA ${ }^{\mathrm{a}}$

\begin{tabular}{l|lr|r|r|r|r}
\multicolumn{1}{c}{ Model } & Sum of Squares & df & Mean Square & \multicolumn{1}{c}{ F } & \multicolumn{1}{c}{ Sig. } \\
\hline 1 & Regression & 2841.985 & 5 & 568.397 & 179.208 & $.000^{\text {b }}$ \\
\cline { 2 - 7 } & Residual & 961.032 & 303 & 3.172 & & \\
\hline Total & 3803.016 & 308 & & & \\
\hline
\end{tabular}

a. Dependent Variable: Purchase Intention

b. Predictors: (Constant), Halal Marketing, Religiosity, Halal Certification, Halal Awareness, Personal Societal Perception

From Table 4, it can be seen that the F value is 179.208 with a significance level of $.000(<0.05)$. This means, all the independent variables in this study have a simultaneously significant influence on the dependent variable. Finally, for the coefficient of determination, this study found an adjusted $\mathrm{R}^{2}$ of 0.747 , which means that the independent variables in this study (i.e., Personal Societal Perception, Religiosity, Halal Awareness, Halal Certification, and Halal Marketing) describe and influence the Purchase Intention of Halal-Certified Personal Care Product by $74.7 \%$. This also means that the other $25.3 \%$ are part of the other independent variables not investigated in this research.

\section{CONCLUSION AND RECOMMENDATION}

\section{Conclusion}

There are some essential findings discovered in this study. First, there is no significant influence between religiosity and purchase intention. This indicates that the Muslim respondents in this research do not consider their religiosity to be an important consideration to shape their intention to purchase halal-certified personal care products. The researchers also found that there is no significant influence between halal awareness and purchase intention. The non-significant findings of religiosity and halal awareness could be partly explained by the fact that for most Muslims, as far as halal goes, they are only "strict" when it comes to foods and beverages, but do not necessarily extend the same judgement to other products such as halal-certified personal care products. Moreover, this study also found that there is a significant influence of personal societal 
perception, halal certification, and halal marketing toward purchase intention, which means that the respondents in this study did consider the halal certification and promotion to be important factors in purchasing personal care products.

\section{Recommendation}

This study discovered some crucial findings that could serve as a general guideline for businesses operating in Indonesia, particularly in the personal care industry, with regard to the growing demand for halal-certified products beyond foods and beverages in light of the recently enacted Law no. 33 of 2014 concerning Halal Product Guarantee. The respondents in this study consider halal certification and halal promotion to be important factors that could shape their intention to purchase personal care products. Unfortunately, according to the Deputy Director of LPPOM MUI which issues halal certification, a lot of companies in Indonesia still downplay the importance of halal-certifying their products (Soraya, 2018) since they have not seen the urgency to do so. The results of this study have clearly demonstrated that halal certification and halal marketing are valuable determinants of Muslim customer's purchase intention, hence justifying the need and importance for personal care brands to halal-certify their products and promote them accordingly to provide these brands with the much-needed competitive advantage in the minds of the customers. Finally, future researchers could incorporate other factors not considered in this research to help explain customer's purchase intention of halal-certified personal care products, such as self-identity (Khan, Asad, \& Mehboob, 2017) and perceived price (Patwary, Mohammed, Hazbar, \& Binti Nor Kamal, 2018; Varinli et al., 2016).

\section{Acknowledgement}

The researchers would like to acknowledge President University for supporting this study through the internal research grant scheme.

\section{REFERENCES}

Abd Rahman, A., Asrarhaghighi, E., \& Ab Rahman, S. (2015). Consumers and Halal cosmetic products: knowledge, religiosity, attitude and intention. Journal of Islamic Marketing, 6(1), 148-163. https://doi.org/10.1108/JIMA-09-2013-0068

Aisyah, M. (2017). Consumer Demand on Halal Cosmetics and Personal Care Products in Indonesia. Al-Iqtishad: Journal of Islamic Economics, 9(1), 125-142. https://doi.org/10.15408/aiq.v9i1.1867

Aiyer, S. (2018). Indonesia can be a $\$ 2.5 \mathrm{~T}$ Economy by 2025 . Retrieved from https://jakartaglobe.id/context/indonesia-can-2-5t-economy-2025/

Ajzen, I. (2015). Consumer attitudes and behavior: the theory of planned behavior applied to food consumption decisions, (2), 121-138. https://doi.org/10.13128/REA-18003

Alam, S., Rohani, M., \& Hisham, B. (2011). Is religiosity an important determinant on Muslim consumer behavior in Malaysia? Journal of Islamic Marketing, 2(1), 83-96. https://doi.org/10.1108/17590831111115268

Alam, S., \& Sayuti, N. (2011). Applying the Theory of Planned Behavior (TPB) in halal food purchasing. International Journal of Commerce and Management, 21(1), 8-20. https://doi.org/10.1108/10569211111111676

Awan, H. M., Siddiquei, A. N., \& Haider, Z. (2015). Factors affecting Halal purchase intention evidence from Pakistan's Halal food sector. Management Research Review, 38(6), 640660. https://doi.org/10.1108/MRR-01-2014-0022

Aziz, Y. A., \& Chok, N. V. (2013). The Role of Halal Awareness, Halal Certification, and Marketing Components in Determining Halal Purchase Intention Among Non-Muslims in Malaysia: A Structural Equation Modeling Approach. Journal of International Food \& 
Agribusiness Marketing, 25(1), 1-23. https://doi.org/10.1080/08974438.2013.723997

Badan Pusat Statistik. (2017). Sensus Penduduk 2010 - Penduduk Menurut Wilayah dan Agama yang Dianut. Retrieved from https://sp2010.bps.go.id/index.php/site/tabel?tid=321

Bakar, A., Lee, R., \& Hazarina Hashim, N. (2013). Parsing religiosity, guilt and materialism on consumer ethics. Journal of Islamic Marketing, 4(3), 232-244. https://doi.org/10.1108/JIMA-04-2012-0018

Bin Jamari, M., Nadzirah, S., Samingin, B., Pandiyan, V., \& Sundram, K. (2011). Muslim's Purchase Intention Towards Non-Muslim's Halal Packaged Food Manufacturer, 3. Retrieved from http://ssrn.com/abstract $=2542873$

Bonne, K., Vermeir, I., Bergeaud-Blackler, F., \& Verbeke, W. (2007). Determinants of halal meat consumption in France. British Food Journal, 109(5), 367-386.

Chairani, D. (2019). Pentingnya Sertifikasi Halal untuk Sebuah Produk. Retrieved from https://www.tribunnews.com/bisnis/2019/03/20/pentingnya-sertifikasi-halal-untuksebuah-produk

EU-Indonesia Business Network. (2019). EIBN Sector Reports: Cosmetics. Indonesian French Chamber of Commerce and Industry. Retrieved from https://indonesien.ahk.de/fileadmin/AHK_Indonesien/Publication/PDF_Publication/EIB N/2019_EIBN_New_Report_-_Sector_Cosmetics.pdf

Euromonitor International. (2015). Doing Business in the Halal Market. Retrieved from http://go.euromonitor.com/rs/805-KOK-719/images/WP_Halal-Market_1.4-0715.pdf

Euromonitor International. (2016). Halal beauty products sales growing rapidly in Indonesia. Retrieved from https://blog.euromonitor.com/2016/09/halal-beauty-products-salesgrowing-rapidly-indonesia.html

Fazira, E., \& Chan, J. (2018). New Consumerism and The Global Halal Market Introduction to Halal. Retrieved from http://go.euromonitor.com/rs/805-KOK-719/images/New Consumerism andThe Global Halal Market Euromonitor.pdf

Garson, B. (2012). Testing Statistical Assumptions. Asheboro: Statistical Associates Publishing.

Haque, A., Anwar, N., Yasmin, F., Sarwar, A., Ibrahim, Z., \& Momen, A. (2015). Purchase Intention of Foreign Products: A Study on Bangladeshi Consumer Prespective. SAGE Open, 5(2), 1-12. https://doi.org/10.1177/2158244015592680

Indonesia Investments. (2017). Cosmetics Indonesia: Rising Demand for Beauty Personal Care Products. Retrieved from https://www.indonesia-investments.com/news/todaysheadlines/cosmetics-indonesia-rising-demand-for-beauty-personal-careproducts/item 8181 ?

Islam, T., \& Chandrasekaran, D. U. (2013). Halal Marketing: Growing The Pie. International Journal of Management Research and Review, 3(12), 3938-3949.

Keller, K. L. (2003). Brand synthesis: the multidemionality of brand knowledge. Journal of Consumer Research, 29(4), 595-600. https://doi.org/10.1086/346254

Khan, M., Asad, H., \& Mehboob, I. (2017). Investigating the consumer behavior for halal endorsed products: Case of an emerging Muslim market. Journal of Islamic Marketing, $8(4), 625-641$.

Kim, H., \& Chung, J. (2011). Consumer purchase intention for organic personal care products. Journal of Consumer Marketing, 28(1), 40-47. Retrieved from https://doi.org/10.1108/07363761111101930

Lada, S., Tanakinjal, H., \& Amin, H. (2009). Predicting intention to choose halal products using theory of reasoned action. International Journal of Islamic Finance and Middle Eastern Finance and Management, 2(1), 66-76.

Lipka, M., \& Hackett, C. (2017). Why Muslims are the world's fastest-growing religious group. Retrieved from https://www.pewresearch.org/fact-tank/2017/04/06/why-muslims-are-the- 
worlds-fastest-growing-religious-group/

Mukhtar, A., \& Mohsin Butt, M. (2012). Intention to choose Halal products: the role of religiosity. Journal of Islamic Marketing, 3(2), 108-120. https://doi.org/10.1108/17590831211232519

Nurcahyo, A., \& Hudrasyah, H. (2017). The Influence of Halal Awareness, Halal Certification, and Personal Societal Perception toward Purchase Intention: A Study Of Instant Noodle Consumption Of College Student In Bandung. Journal of Business and Management, 6(1), 21-31. Retrieved from http://journal.sbm.itb.ac.id/index.php/jbm/article/viewFile/2137/1111

Patwary, A., Mohammed, A., Hazbar, A., \& Binti Nor Kamal, N. (2018). Factors influencing consumers' intentions towards purchasing Islamic hotel service: Moderating role of religiosity. International Journal of Management, Accounting and Economics, 5(7), 482497.

Permana, F. (2019). 688.615 Produk Disertifikasi Halal Sejak 2012 Hingga 2018. Retrieved from https://www.republika.co.id/berita/dunia-islam/islam-nusantara/19/01/17/plf0dn384688615-produk-disertifikasi-halal-sejak-2012-\%0A101\%0Ahingga-2018

Pew Research Center. (2011). The Future of the Global Muslim Population. Retrieved from https://www.pewforum.org/2011/01/27/the-future-of-the-global-muslim-population/

Sekaran, U., \& Bougie, R. (2016). Research methods for business: A skill building approach. John Wiley \& Sons, Ltd.

Shah Alam, S., \& Mohamed Sayuti, N. (2011). Applying the Theory of Planned Behavior (TPB) in halal food purchasing. International Journal of Commerce and Management, 21(1), 820. https://doi.org/10.1108/10569211111111676

Soraya, D. (2018). Ini Alasan Pentingnya Sertifikasi Halal. Retrieved from https://www.republika.co.id/berita/dunia-islam/islam-nusantara/18/10/22/pgznr4396-inialasan-pentingnya-sertifikasi-halal

Spencer, N. (2016). Indonesia leads halal innovation. Retrieved from https://www.cosmeticsdesign-asia.com/Article/2016/12/13/Indonesia-leads-halalinnovation

Syukur, M., \& Nimsai, S. (2018). Factors Influencing the Purchase Intention of Halal Packaged Food in Thailand. International Journal of Supply Chain Management, 7(4), 2051-3771.

The Jakarta Post. (2017). Indonesia told to develop halal industry. Retrieved from http://www.thejakartapost.com/news/2017/06/14/indonesia-told-to-develop-halalindustry.html

Thomson Reuters. (2016). State of the Global Islamic Economy Report. Retrieved from https://ceif.iba.edu.pk/pdf/ThomsonReutersstateoftheGlobalIslamicEconomyReport201617.pdf

Varinli, İ., Erdem, E., \& Avcilar, M. (2016). Exploring the Factors Affecting Purchase Intention of Halal Certified Foods in Turkey: A PLS-Path Modeling Study. European Journal of Business and Management, 8(4), 68-78.

Weng, T., \& Khin, A. (2017). Consumer attitude toward intention to purchase green foods in chicken meet industry. International Journal of Advanced and Applied Sciences, 4(4), $155-158$.

Wilson, J. A. J., \& Liu, J. (2010). Shaping the Halal into a brand? Journal of Islamic Marketing, l(2), 107-123. https://doi.org/10.1108/17590831011055851

Xiao, J. J., Ford, M. W., \& Kim, J. (2011). Consumer Financial Behavior: An Interdisciplinary Review of Selected Theories and Research. Family and COnsumer Sciences Research Journal, 39(4), 399-414. 